\title{
POLITIK HUKUM PENGATURAN PROFESI PERAWAT DALAM UPAYA STANDARDISASI MASYARAKAT EKONOMI ASEAN (MEA)
}

\author{
LEGAL POLITIC REGULATION OF NURSERY IN ORDER \\ TO MEET THE ASEAN ECONOMIC COMMUNITY \\ STANDARDIZATION
}

\author{
Yohanes Hermanto Sirait, \\ *Dosen Fakultas Hukum Universitas Kristen Maranatha \\ email : yohanessirait1988@gmail.com \\ Demson Tiopan \\ *Dosen Fakultas Hukum Universitas Kristen Maranatha \\ email : demsontiopan@gmail.com
}

Naskah diterima : 19/01/2018; direvisi : 26/03/2018; disetujui : 27/04/2018

\begin{abstract}
Mutual Recognition Agreement (MRA) that have been agreed in conjunction with ASEAN Economi Community (AEC), mandate the free flow of worker, one of which is Nurse. With this MRA on Nurse, the nurses originated from ASEAN have better access to work in other ASEAN states. However, MRA on Nurse has to face some problems in difference of education level, permissions, payment and dispute settlement. This article aims to examine legal policy on harmonization in regulating nurse in Indonesia in order to fulfill the standard of nurse regulation which mandated by AEC and MRA on Nurse. This article is normative research, use secondary data which obtained through library research and interview as addition data. This article present deductively. The result show that there are some problems in process of harmonization in Indonesia, specifically Law Number 35 year 2014 on Nursery, as main regulation on nurse, legitimated before the implementation of AEC. It means this law still not fulfill the standard of AEC. Therefore, Indonesia need to harmonize the regulation on nursery according to each standard mandated by AEC and MRA on Nurse.
\end{abstract}

Keywords: Legal Polocy; Nurse; ASEAN Economic Community.

\begin{abstract}
Abstrak
Mutual Recognition Agreement (MRA) yang disepakati untuk diberlakukan bersamaan dengan MEA mengamanatkan arus bebas tenaga kerja yang salah satunya adalah profesi perawat. Dengan adanya MRA Perawat ini maka perawat yang berasal dari Negara ASEAN dapat lebih mudah bekerja di Negara ASEAN lainnya. Namun MRA Perawat dihadapkan pada persoalan perbedaan dalam hal tingkat pendidikan, perizinan, pengupahan dan penyelesaian sengketa. Tulisan ini bertujuan untuk mengkaji politik hukum harmonisasi pengaturan tentang keperawatan di Indonesia agar dapat menyesuaikan standar pengaturan keperawatan yang diamanatkan dalam MEA dan MRA Perawat. Penelitian ini merupakan penelitian hukum normatif dengan menggunakan data sekunder yang diperoleh melalui studi pustaka dan hasil wawancara sebagai data tambahan. Pengkajian dilakukan secara deduktif. Hasil penelitian mengidentifikasi beberapa masalah dalam proses harmonisasi
\end{abstract}


yaitu pengaturan tentang keperawatan baru diatur secara tegas dalam UU No. 35 Tahun 2014 tentang Keperawatan. Oleh karena UU ini disahkan sebelum berlakunya MEA, terdapat kemungkinan bahwa muatannya belum memenuhi standar yang disepakati di MEA. Untuk itu, Indonesia perlu melakukan harmonisasi pengaturan profesi perawat sesuai standar yang diamanatkan dalam MEA dan MRA Perawat.

\section{Keywords: Politik Hukum; Perawat; Masyarakat Ekonomi ASEAN (MEA).}

\section{PENDAHULUAN}

Masyarakat Ekonomi ASEAN (MEA) sudah berjalan sejak awal tahun 2016 ini. Tidak siap dan takut bersaing tidak perlu diperdebatkan saat ini namun persiapan untuk bersainglah yang perlu ditingkatkan agar Indonesia menjadi bagian dari kesuksesan MEA bukan sebaliknya. Hal ini penting dilakukan mengingat tingkat pengangguran di Indonesia tercatat 5,5\% per Februari $2016{ }^{1}$, tertinggal jauh dari negara tetangga seperti Thailand $(0,8 \%)$, Singapura (2\%) dan Malaysia (2,9\%). Jika merujuk pada data ini, kaum yang optimis akan mengatakan bahwa MEA membawa keuntungan dengan terbukanya lapangan pekerjaan di seluruh wilayah ASEAN sebagaimana yang telah disepakati dalam Mutual Recognition Agreements (MRA) sedangkan kaum pesimis akan takut jika harus juga bersaing dengan pemangku profesi asal Negara anggota ASEAN lainnya.

Telah disepakati bahwa delapan profesi yang difalisitasi arus bebas tenaga kerja adalah insinyur, arsitektur, perawat, dokter, dokter gigi, akuntan, land surveyor, dan pekerja pariwisata. Tugas berat dari pemerintah Indonesia adalah melakukan harmonisasi standard dan pengaturan terkait profesi-profesi tersebut. Terkait dengan delapan profesi tersebut, Indonesia saat ini mempunyai angka pengangguran yang tinggi $(5,5 \%)$, Asosiasi Profesi Tenaga Terampil dan Ahli Indonesia (APTA) menyatakan bahwa hingga 2019, Indonesia akan mengalami defisit 120.000

${ }^{1}$ Tempo, Jumlah Pengangguran RI 5,5 Persen per Februari 2016, 17 Agustus 2016, https://bisnis.tempo.co/ $\mathrm{read} /$ news/2016/08/17/090796741/jumlah-pengangguran-ri-5-5-persen-per-februari-2016, diakses tanggal 5 Oktober 2016.
Insinyur Sipil dan defisit 190.000 Tenaga Medis. Diantara profesi tenaga medis yang menjadi perhatian, profesi perawat merupakan profesi yang perlu disoroti dan diperhatikan kondisinya mengingat saat ini di Indonesia sudah dikeluarkan Undang-Undang Nomor 38 Tahun 2014 tentang Keperawatan (untuk selanjutnya disebut UU Keperawatan).

Lahirnya UU Keperawatan ini merupakan babak baru dalam dunia keperawatan dan memberikan jaminan hukum bagi para perawat dan pasien yang ditangani. Dengan adanya legitimasi dalam bentuk UU, diharapkan agar pemerintah mampu mengarahkan para perawat untuk bekerja secara profesional, terlatih, dan mampu mendorong perawat untuk bekerja dan berperilaku baik, serta tidak pernah menanggalkan empati kepada mereka yang diberikan pelayanan sehingga layaklah perawat dikategorikan sebagai suatu profesi².

Dilihat dari sisi historis, terdapat perubahan paradigma terkait profesi perawat di Indonesia saat ini. Pekerjaan perawat yang semula vokasional $^{3}$ digeser menjadi pekerjaan profesional. Perawat yang dulunya berfungsi sebagai perpanjangan tangan atau sekedar

\footnotetext{
${ }^{2}$ Kamus Besar Bahasa Indonesia menyatakan bahwa profesi adalah bidang pekerjaan yang dilandasi pendidikan keahlian (keterampilan, kejuruan, dan sebagainya) tertentu. Profesi adalah suatu pekerjaan atau atau jabatan yang menuntut keahlian dari para petugasnya. Profesi biasanya memiliki asosiasi profesi, kode etik, serta proses sertifikasi dan lisensiyang khusus untuk bidang profesi tersebut.

${ }^{3}$ Paradigma pendidikan vokasi sangat berbeda yaitu menekankan pada pendidikan yang menyesuaikan dengan permintaan pasar (demand driven). Kebersambungan (link) diantara pengguna lulusan pendidikan dan penyelenggara pendidikan dan kecocokan (match) diantara tenaga kerja dengan pemberi kerja menjadi dasar penyelenggaraan dan ukuran keberhasilan pendidikan vokasi.
} 
"pembantu" dokter, kini dapat dipandang sebagai mitra sejajar dokter sebagaimana para perawat di negara maju. Perubahan paradigma ini diawali pada Loka karya Nasional Keperawatan I Tahun 1983, dalam pertemuan itu disepakati bahwa keperawatan adalah pelayanan profesional. $^{4}$

Dengan adanya UU Keperawatan dan Peraturan-peraturan terkait tentang profesi perawat, saat ini kegiatan keperawatan semakin terjamin dan jelas namun persoalan baru justru saat ini atau tepatnya 2 tahun sejak UU Keperawatan disahkan. Dengan adanya MEA, maka peraturan tentang keperawatan di Indonesia harus merujuk pada standar keperawatan yang disepakati dengan berlangsungnya RMA di MEA. Hal ini berkaitan juga dengan standar keperawatan, perlindungan hukum profesi perawat termasuk perawat asing yang akan bekerja di Indonesia dan bagaimana penyelesaian hukum dalam hal terjadi masalah hukum antara perawat asing dengan pasien di Indonesia sehingga politik hukum dalam proses harmonisasi pengaturan keperawatan menjadi suatu yang krusial dan layak dikaji.

Berbagai tujuan dan alasan dibentuknya peraturan perundangundangan disebut juga sebagai politik hukum (legal policy). Dalam perumusan perundang-undangan, politik hukum ini menjadi penting dengan alasan untuk mengetahui kenapa diperlukan pembentukan peraturan perundangundangan dan untuk menentukan apa yang hendak dimuat atau diatur dalam peraturan perundang-undangan tersebut termasuk muatan-muatan dalam Pasal. ${ }^{5}$ Dalam konteks MEA, politik hukum ini penting untuk mengetahui tujuan harmonisasi pengaturan keperawatan dilakukan (sering disebut sebagai dimensi

${ }^{4}$ Prihadjo, Praktik Keperawatan Profesional Konsep Dasar dan Hukum, Jakarta : EGC, 1995, hlm.18

5 Hikmahanto Juwana, Politik Hukum UU Bidang Ekonomi di Indonesia, Jurnal Hukum, 2005, Vol. 01, No. 1, hlm. 24. kebijakan

pemberlakuan/enactment policy $)^{6}$ dan apa yang perlu diatur dalam peraturan perundang-undangan tentang keperawatan diIndonesia. Dikeluarkannya UU Keperawatan sebelum MEA berlaku bisa jadi bagian dari politik hukum itu sendiri yakni persiapan menjelang MEA.

Politik hukum harmonisasi pengaturan keperawatan harus didasarkan pada landasan yang tepat. Landasan tersebut dapat berupa landasan idil dan landasan operasional. Landasan idil merupakan dasar utama karena diambil dari norma terdasar (ground norm) dari suatu negara dalam konteks Indonesia yakni Pancasila sedangkan landasan operasional dapat dilihat dalam beberapa aspek yakni keadilan, kesejahteraan, demokrasi, kesatuan, perlindungan HAM dan kedaulatan. ${ }^{7}$ Landasan-landasan tersebut hendaknya diakomodir dan tidak dikesampingkan meskipun konteks MEA lebih berbicara pada liberalisasi perdagangan dan secara khusus liberalisasi tenaga kerja. Negara berdaulat hendaknya mampu mengutamakan kepentingan nasional dan mewujudkan negara kesejahteraan (welfare states).

Penelitian ini dimaksudkan untuk menjawab pokok masalah politik hukum harmonisasi pengaturan tentang keperawatan di Indonesia guna menyesuaikan standar pengaturan keperawatan yang diamanatkan dalam MEA. Selain itu, penelitian ini juga dimaksudkan untuk mengkaji dan menganalisa kendala dan solusi yang dibutuhkan dalam proses harmonisasi pengaturan tentang keperawatan di

${ }^{6}$ Kebijakan pemberlakuan sangat dominan di negara berkembang mengingat peraturan perundang-undangna kerap dijadikan instrumen politik oleh pemerintah atau penguasa. Dalam konteks negatif, manusia dibuat untuk hukum (rule by law) dan dalam konteks positif, hukum dibuat untuk manusia (rule of law). Ibid, hlm. 25

${ }^{7}$ M. Ilham F. Putuhena, Politik Hukum Perundang-undangan: Mempertegas Reformasi Legislasi yang Progresif, Jurnal Rechtsvinding, Media Pembinaan Hukum Nasional, 2013, Vol.2, No. 3, hlm. 383. 
Indonesia dalam konteks berlakunya MEA.

\section{Politik Hukum dan Harmonisasi Hu- kum}

Terdapat2 (tiga) poin penting yang perlu diperhatikan untuk dapat menemukan hubungan antara perdagangan bebas dan hukum yang mengaturnya (hukum ekonomi internasional). Pertama, hukum ekonomi internasional merupakan hukum publik karena mengatur hubungan ekonomi antar negara bahkan sampai pada konteks antar individu dan perusahaan termasuk juga intstitusi atau entitas yang terkait seperti WTO dan ASEAN. Kedua, hukum ekonomi akan menyentuh halhal yang berkenaan dengan teori politik oleh karena ada upaya pengalokasian atau pengalihan hak, sumber daya dan kesempatan dari satu entitas ke entitas lainnya. ${ }^{8}$

Merujuk pada poin diatas bahwa hukum ekonomi internasional atau hukum perdagangan internasional (dalam tataran yang lebih mikro) merupakan hukum publik ${ }^{9}$ karena mengatur kepentingan publik. Oleh sebab itu dalam hal harmonisasi pengatuaran keperawatan dalam hubungan dengan MEA dilakukan akan berkaitan erat dengan kepentingan publik. Kepentingan publik disini adalah dalam kaitannya dengan negara atau pemerintah sebagai pembuat atau pelaku harmonisasi hukum dan perawat sebagai warga negara termasuk setiap warga negara yang menggunakan jasa perawat. Ketika MRA dalam MEA diberlakukan, warga negara asing yang berprofesi sebagai perawat dapat memasuki dan bekerja di Indonesia. Oleh karena Indonesia adalah

\footnotetext{
${ }^{8}$ Frank Garcia, Theories of Justice and International Economic Law, Research Handbook on Global Justice and International Economic Law John Linarelli ed. Northhampton, MA: Edward Elgar, 2013, hlm. 1.

9 Hukum Publik adalah Hukum yang mengatur hubungan antara negara dengan alat-alat perlengkapan atau hubungan antara negara dengan warga negaranya. Lihat, C.S.T. Kansil, Pengantar Ilmu Hukum, Jakarta: Balai Pustaka, 2002, hlm. 46.
}

negara hukum maka sudah selayaknya pengaturan mengenai perlindungan hukum tidak hanya diberikan kepada perawat asal Indonesia tetapi juga perawat asing yang bekerja di Indonesia. Dalam hal kewajiban ini tidak dilaksanakan maka tujuan dan manfaat dari MEA tidak akan maksimal dan bahkan Indonesia dapat dianggap wanprestasi karena melanggar kesepakatan dalam MEA.

Sebagaimana disampaikan sebelumnya, perdagangan bebas juga erat kaitannya dengan kegiatan politik sehingga teori politik dan praktik terbaik (best practice) dalam berpolitik harus diterapkan. Definisi politik sangat variatif, ada yang berpandangan positif dan ada yang negatif. Politik sering didefinisikan sebagai penggunaan kekuasaan atau kewenangan, suatu proses pembuatan keputusan secara kolektif, suatu alokasi sumberdaya yang langka (the allocation of scarce resources), atau sebagai arena pertarungan kepentingan yang penuh muslihat. ${ }^{10}$ Meskipun demikian, politik pada hakikatnya adalah seni tentang mencapai suatu tujuan dari suatu perbedaan.

Jika politik dihubungkan dengan ilmu hukum maka dikenal dengan istilah politik hukum. Setiap negara termasuk negara-negara di ASEAN memiliki politik hukum sendiri yang perannya sebagai kebijakan dasar bagi penyelenggara negara untuk menentukan arah, bentuk maupun isi hukum yang akan dibentuk. Oleh karena harmonisasi juga mengharuskan pembentukan hukum maka politik hukum tetap menjadi suatu yang penting. Ketika politik hukum menjadi bahan kajian, sebenarnya unsur politik sudah dilepaskan, oleh karena politik hukum lebih pada penggabungan antara ilmu hukum dan filsafat hukum. ${ }^{11}$ Sehingga pada penelitian

\footnotetext{
${ }^{10}$ Andrew Heywood, Political Theory: An Introduction, 3rd Edition, New York: Palgrave Macmillan, 2004, hlm. 52.

11 Sri Soemantri, Prosedur dan Sistem Perubahan Konstitusi Dalam Batang Tubuh UUD 45 (sebelum dan
} 
ini, penulis tidak akan memberikan porsi besar terkait dengan politik. Hal ini juga didasarkan pada fakta bahwa urusan politik sudah selesai ketika pemerintah Indonesia melalui Kementerian Luar Negeri dan Diplomatnya menyepakati kerangka MEA dalam ASEAN termasuk kerangka arus bebas profesi perawat.

Lebih lanjut, konsep harmonisasi didasari pada fakta keberagaman substansi hukum, struktur hukum dan budaya hukum. Negara-negara di dunia memiliki pandangan masing-masing mengenai hukum dan apa yang dimuat dalam hukum sehingga terjadi yang namanya disharmoni hukum. Untuk itu harmonisasi hukum sebenarnya dibutuhkan. Harmonisasi hukum bertujuan melakukan penyesuaian segala bentuk peraturan perundangundangan yang dapat membawa pada kepastian hukum, keadilan hukum dan kemanfaatan hukum. Harmonisasi hukum sendiri memiliki fungsi pencegahan dan penanggulangan. Dalam konteks pengaturan keperawatan, harmonisasi hukum ditujukan untuk mencegah adanya gap atau kesenjangan antara perawat asal Indonesia dan perawat asal negara anggota ASEAN lainnya. Gap atau kesenjangan ini dapat dijembatani dengan adanya harmonisasi standar dan sertifikasi perawat di ASEAN sehingga arus bebas profesi perawat di Indonesia dapat berjalan tanpa hambatan berarti. Sedangkan fungsi penaggulangan dapat dikaitkan dengan penyelesaian masalah dalam praktek keperawatan dalam kerangka MEA. Choice of law (pilihan hukum) menjadi suatu persoalan yang perlu diperhatikan juga.

\section{Profesi Keperawatan di Indonesia dan Mutual Recognition Agreement terkait Perawat di ASEAN}

Berdasarkan data, lulusan perawat di berbagai lembaga pendidikan setiap tahun

Sesudah Perubahan UUD 45), Bandung: Alumni, 2006, hlm. 35 . sekitar 40.000 perawat baru, dengan rasio terhadap jumlah penduduk 1 : 2850 . Dengan keterbatasan jumlah lulusan tenaga keperawatan yang dalam konteks ini termasuk bidan ternyata daya serap diatur dalam lulusan tenaga kesehatan (keperawatan dan kebidanan) oleh jaringan pelayanan kesehatan ternyata masih sangat rendah dan terbatas. ${ }^{12}$

Berkenaan pelayanan kesehatan yang belum merata di seluruh wilayah Indonesia, utamanya di pedesaan, daerah terpencil yang jauh dari pusatpusat pelayanan kesehatan, profesi perawat sangat dominan dan diminati serta bagaikan dewa penolong bagi warga masyarakat yang membutuhkan. Kemampuan profesi yang standar dan mudah berinteraksi dengan masyarakat berbagai lapisan, dengan biaya yang murah bahkan bisa dengan barter ataupun gratis, perawat menjadi barisan terdepan untuk melayani kesehatan selama 24 jam.

Pelayanan keperawatan profesional hanya dapat diberikan oleh tenaga keperawatan profesional yang telah memiliki izin dan kewenangan untuk melakukan tindakan keperawatan yang dibutuhkan oleh sistem pasien. Pengaturan tindakan keperawatan diatur dalam suatu sistem regulasi keperawatan. Sistem regulasi praktik keperawatan terjadi dalam suatu kontinum restriktif sampai paling restriktif yaitu designasi atau rekognasi, registrasi, sertifikasi, dan lisensi. Designasi atau rekognisi merupakan proses pengakuan terhadap seseorang yang telah menyelesaikan pendidikan keperawatan dan mendapatkan ijazah. ${ }^{13}$

Keluarnya Undang-undang Nomor 23 Tahun 1992 tentang Kesehatan yang kemudian diamandemen dengan UndangUndang Nomor 36 Tahun 2009 tentang Kesehatan, UndangUndang Nomor 20 Tahun 2003 tentang

\footnotetext{
${ }^{12}$ Marius Widjajarta, Laporan Akhir Tim Pengkajian tentang Hak dan Kewajiaban Tenaga Kesehatan, Badan Pembinaan Hukum Nasional, 2011, hlm. 13.

${ }^{13}$ Ibid, hlm. 52
} 
Sistem Pendidikan Nasional, Peraturan Pemerintah Nomor 32 Tahun 2001 Tentang Tenaga Kesehatan, Surat Keputusan Menteri Kesehatan Nomor 1239 Tahun 2001 tentang Registrasi dan Praktik Perawat, dan Peraturan Menteri Kesehatan Nomor 148 Tahun 2010 tentang Izin dan penyelenggaraan Praktik Perawat lebih mengukuhkan perawat sebagai perawat di Indonesia, kewenangan perawat dalam menjalankan tugas profesi diatur dalam Permenkes Nomor 148/2010 sehingga perawat mempunyai legitimasi dalam menjalankan praktik profesinya.

Di tengah keterbatasan jumlah perawat yang berprofesi di dalam unit pelayanan kesehatan sampai dengan di rumah sakit pemerintah, baik rumah sakit umum pusat sampai dengan rumah sakit umum daerah, rumah sakit khusus, dan pusat kesehatan masyarakat (Puskesmas), lulusan pendidikan keperawatan dari jenjang SMK sampai magister mencapai $24000-25000$ orang per tahun. Namun hanya 4 - 10 persen diantara mereka yang terserap pasar kerja di lembaga kesehatan pemerintah dan swasta. Rendahnya daya serap lulusan pendidikan keperawatan merupakan imbas terbatasnya anggaran pemerintah. Hal ini semakin menjadi perdebatan setelah Indonesia ikut serta dalam MRA ASEAN yang didalamnya terdapat kesepakatan arus bebas tenaga kerja perawat.

Arus bebas tenaga kerja di ASEAN sebenarnya bukanlah bagian utama dalam kesepakatan di Deklarasi asli ASEAN namun sejak diadopsinya ASEAN Framework Agreement on Services (AFAS) pada tahun 15 Desember 1995 di Bangkok, Thailand dan kesepakatan tentang Movement of Natural Persons (MNP), wacana mengenai arus bebas tenaga kerja menjadi sesuatu yang penting. Sampai pada akhirnya disepakati suatu persetujuan mengenai hal ini dalam Mutual Recognition
Arrangement (MRA). ${ }^{14}$ Bingkai tersebut didasari pada ide bahwa ASEAN harus juga mulai bekerja sama terkait dengan layanan perdagangan jasa di tingkat ASEAN. Bingkai tersebut kemudian lebih dipertegas pada Konferensi ke -7 ( $7^{\text {th }}$ Summit) pada bulan November tahun 2001.

Beberapa tahun kemudian, ide perdagangan jasa tersebut mulai menunjukkan tanda-tanda penguatan dengan ditandatanganinya arus bebas jasa salah satu profesi yakni Insinyur pada tanggal 9 Desember 2005, kemudian dilanjutkan dengan profesi Perawat pada tanggal 8 Desember 2006, Arsitek dan Surveyor pada tanggal 19 November 2007, Tenaga Kesehatan dan Dokter Gigi pada tanggal 26 Februari 2009. Sebenarnya pada tanggal 26 Februari 2009, bingkai MRA untuk profesi akuntan sudah dibuat namun baru ditandatangani pada tanggal 13 November 2014 setelah sebelumnya ditandatangani untuk profesi Tenaga Pariwisata pada tanggal 9 November 2012. Jadi, sejauh ini terdapat 8 profesi yang sudah disepakati dalam MRA sehingga terhadap profesi-profesi tersebut, negara anggota ASEAN sepakat adanya arus bebas tenaga kerja.

Untuk memulai proses liberalisasi jasa tersebut dilakukan dengan menghilangkan hambatan terkait penyedia jasa dan pengguna jasa melalui 4 (empat) cara yang dikenal sebagai mode of supply, yaitu: ${ }^{15}$
a. "Mode I (Cross-Border Supply) merupakan jasa yang diberikan oleh penyedia jasa luar negeri kepada pengguna jasa dalam negeri. Contoh: Jasa Advokat.

\footnotetext{
14 Flavia Jurje dan Sandra Lavenex, ASEAN Economic Community: what model for labour mobility?, Bern: World Trade Institute of the University of Bern Working Paper, 2015, No.2015/02. hlm. 3 .

15 Aida S. Budiman, Masyarakat Ekonomi ASEAN 2015, Jakarta: Media Komputindo, 2008, hlm. 1., sebagaimana dikutip dari Cindy Cephanie Manek, Implikasi Pemberlakuan Ketentuan ASEAN Framework Agreement on Services (AFAS) Terhadap Jabatan Notaris, Denpasar: Magister Kenotariatan, 2014, hlm. 74.
} 
b. Mode 2 (Consumption Abroad) merupakan jasa yang diberikan oleh penyediajasa diluar negeri kepada konsumen domestik yang sedang berada di negara penyedia jasa. Contoh: Jasa perawatan medis di Rumah Sakit.

c. Mode 3 (Commercial Presence) merupakan jasa yang disediakan dengan kehadiran penyedia jasa dari luar negeri kepada konsumen di negara konsumen. Contoh: Pendirian Rumah Sakit asal Singapura di Indonesia.

d. Mode 4 (Movement of Individual Service Providers) merupakan penyediaan jasa berupa TKA yang memiliki keahlian tertentu kepada konsumen di negara konsumen. Contoh: Praktik Profesi Dokter asal Singapura di Indonesia."

MRA berkaitan dengan arus bebas tenaga profesional antar Negara anggota ASEAN. Dikatakan profesional, karena disepakati bahwa terhadap profesi yang diakui dalam MRA, harus yang sudah diakui, berlisensi atau setidaknya terdapat sertifikat yang menyatakan kompetensi dari tenaga kerja tersebut.

Oleh karena MRA juga memerlukan kesiapan dalam negeri terkait kualifikasi dan sertifikasi dari berbagai jenis profesi ${ }^{16}$, komite-komite telah dibentuk untuk mengimplementasi seluruh MRA yang telah disepakati dan masing-masing MRA tersebut memiliki mekanismenya tersendiri terkait pengakuan dan fasilitasi tenaga profesional berkualifikasi di ASEAN. MRA juga memungkinkan negara-negara anggota penandatangan saling mengakui standar kualifikasi tenaga profesional antar negara, sehingga memfasilitasi gerakan yang lebih mudah bagi tenaga kerja profesional di kawasan ASEAN. ${ }^{17}$

16 Silvi Ch. Suman, Perkembangan ASEAN Framework Agreement on Services (AFAS) dan Kesiapan Indonesia, Buletin KPI, 2011, Edisi OOL/ $\mathrm{KP} / 2011$, hlm. 43.

17 Lalu lintas tenaga kerja diatur dalam ASEAN Framework Agreement on Services (AFAS) moda 4 tentang fasilitas pergerakan penyedia jasa tenaga kerja profesional. Pasal 5 AFAS berbunyi: "Setiap negara ang-
MRA diharapkan menjadi awal dari arus bebas tenaga kerja di ASEAN. Kesuksesan migrasi 8 profesi yang disepakati dalam MRA akan menjadi gambaran dan preseden kedepannya untuk memasukkan profesi lainnya dalam MRA. Namun, kesuksesan MRA sangat dipengaruhi oleh kemampuan negara anggota ASEAN untuk terus bekerja sama. Pembuat kebijakan (pemimpin negara) harus memberikan perhatian khusus terkait: ${ }^{18}$

a. "Memperluas MRA dan membangun jaringan ke akses pasar yang jelas. Negara anggota ASEAN harus mulai memikirkan profesi lainnya yang bisa disepakatimenikmatifasilitasarusbebas. Profesi di bidang IT dan kuliner adalah salah satu contoh yang dapat digarap bersama.

b. Menghapuskan ketentuan nasionalyang menghambat arus bebas profesi-profesi yang sudah disepakati.

c. Memperluas akses pasar tenaga kerja dengan keahlian rendah (low-skilled workers) melalui suatu skema yang bersifat sementara.

d. Melindung hak tenaga kerja tidak terdokumentasi (irregular workers).

e. Memudahkan pengurusan jaminan sosial bagi tenaga kerja. Jaminan sosial menjadi penting dalam hal pengupahan, tunjangan dan dana pensiun. KeberhasilanMRAdipengaruhiolehpola pikir tenaga kerja yang merasa amanjika bekerja di negara ASEAN lainnya."

MRA adalah instrumen utama untuk mobilitas tenaga kerja terampil di ASEAN. Namun, pengakuan kualifikasi dan pengalaman tenaga kerja tidak langsung menjamin akses pasar. Terdapat hambatan-hambatan yang membatasi

gota dapat mengakui pendidikan atau pengalaman yang di dapat, sesuai dengan persyaatan, ataupun lisensi atau sertifikat yang diberikan oleh Negara anggota lainnya, guna memberikan lisensi atau sertifikat terhadap pensuplai jasa."

${ }^{18}$ Sarah Huelser dan Adam Heal, Moving Freely? Labour Mobility in ASEAN, ARTNeT Policy Brief, 2014, No. 40, hlm. 8 - 9. 
pergerakan tenaga kerja terampil tersebut. Kebijakan dan kerangka peraturan yang menghambat mobilitas tenaga kerja terampil mencakup persyaratan dan prosedur untuk visa kerja dan melewati lapangan kerja; ketentuan-ketentuan konstitusional pemesanan pekerjaan bagi warga negara; kebijakan yang menutup atau memaksakan pada profesional asing dan keterampilan dalam sektor dan pekerjaan; tes pasar ekonomi dan tenaga kerja yang membatasi kerja asing dan membutuhkan telah mereka diganti oleh penduduk setempat dalam jangka waktu yang ditetapkan; peraturan perizinan dari asosiasi profesional; dan persyaratan kemampuan berbahasa. Negara harus bekerja sama untuk meminimalkan hambatan. Pertukaran informasi dan transparansi dan menyederhanakan visa dan izin kerja dengan aplikasi akan sangat membantu. ${ }^{19}$

Free movement of workers (arus bebas tenaga kerja) merupakan salah satu kesepakatan utama dalam Pasar Tunggal MEA yang telah disepakati oleh negaranegara anggota ASEAN. Meskipun demikian, sebenarnya sebelum MEA diberlakukan, migrasi tenaga kerja sudah terjadi antar negara anggota ASEAN namun kebanyakan migrasi adalah tenaga kerja tidak profesional dan bahkan tenaga kerja tidak berdokumen (irregular workers). ${ }^{20}$ Seiring dengan ditandatanganinya Piagam ASEAN pada 20 November 2007, liberalisasi perdagangan termasuk arus bebas tenaga

${ }^{19}$ Chia, S. Y. , Free Flow of Skilled Labor in the AEC', in Urata, S. and M. Okabe (eds.), Toward a Competitive ASEAN Single Market: Sectoral Analysis. ERIA Research Project Report, 2011, No. 2010-03, hlm. 205.

${ }_{20}$ Irregular migration merupakan istilah yang dugunakan oleh International Organization of Migration untuk mendefinisikan proses migrasi yang tidak sesuai dengan norma dan aturan yang berlaku. Istilah ini digunakan untuk membedakan dengan migrasi illegal yang cenderung mengandung unsur penyeludupun tenaga kerja. Lihat, Sarah Huelser dan Adam Heal, Moving Freely? Labour Mobility in ASEAN, ARTNeT Policy Brief ,2014, No. 40, hlm. 2, lihat juga, www.artnetontrade.org, diakses tanggal 12 Oktober 2016, pukul 15.50 WIB. kerja memiliki legitimasi hukum yang jelas.

Terdapat dua tipe arus tenaga kerja, pertama, arus yang paling besar dari tenaga kerja tidak terampil dan semi terampil. Kedua, yang jauh lebih kecil adalah arus profesional dan tenaga kerja terampil. Aspirasi arus bebas tenaga kerja terampil MEA berbeda dengan sifat arus migrasi intra-negara ASEAN saat ini. Kebanyakan pendatang intra-ASEAN adalah pekerja tidak terampil (lebih dari $87 \%$ yang berketerampilan rendah), dan migrasi ilegal masih merupakan masalah yang sulit dipecahkan. ${ }^{21}$ MEA sendiri hanya mencakup arus bebas tenaga kerja terampil, dan tidak mengurusi tenaga kerja tidak terampil maupun semi-terampil. Harapannya adalah dengan aliran bebas tenaga kerja terampil akan memberi implikasi penting bagi perdagangan jasa, investasi langsung luar negeri (foreign direct investment /FDI) dan pertumbuhan produktivitas.

Pasal 1 (5) Piagam ASEAN menyatakan bahwa "To create a single market and production base which is stable, prosperous, highly competitive and economically integrated with effective facilitation for trade and investment in which there is free flow of goods, services and investment; facilitated movement of business persons, professionals, talents and labour; and freer flow of capital."(untuk menciptakan pasar tunggal dan basis produksi yang stabil, sejahtera, berdaya saing tinggi dan secara ekonomi terintegrasi dengan penyediaan fasilitas yang efektif bagi perdagangan dan investasi di mana terdapat arus barang, jasa dan investasi yang bebas, pergerakan pebisnis yang difasilitasi, profesional, bakat dan tenaga kerja, dan arus modal yang lebih bebas).

\footnotetext{
${ }^{21}$ Guntur Sugiyarto and Dovelyn Rannveig Agunias. A 'Freer' Flow of Skilled Labour within ASEAN: Aspirations, Opportunities and Challenges in 2015 and Beyond, Bangkok and Washington, D.C.: International Organization for Migration and Migration Policy Institute. 2014.
} 
Visi MEA untuk menciptakan pasar tunggal akan sulit tercipta tanpa adanya arus bebas tenaga kerja terampil untuk memberikan pelayanan dan liberalisasi FDI. MEA memberi konsekuensi bahwa setiap negara peserta harus memberikan izin terhadap lalu lintas keluar masuk tenaga kerja terampil yang terlibat dalam perdagangan barang, jasa, dan investasi sesuai dengan peraturan yang berlaku di negara bersangkutan. Negara harus berusaha untuk menghapus sejauh mungkin hambatan aliran bebas tenaga kerja terampil dan lebih memfasilitasi transparansi pertukaran informasi, memfasilitasi penerbitan visa dan employment pass bagi tenaga kerja terampil ASEAN yang bekerja di sektor-sektor yang berhubungan dengan perdagangan dan investasi antar negara ASEAN ${ }^{22}$, termasuk menyediakan aplikasi yang dapat menyederhanakan proses pengurusan visa dan izin kerja.

Terdapat beberapa aspek ketenagakerjaan yang berhubungan dengan kerjasama migrasi di tingkat regional yang harus ditangani dalam kerangka MEA. Walaupun tidak diterjemahkan ke dalam kebijakan langsung dan wajib bagi negara-negara ASEAN, aspek tersebut membutuhkan tindakan nyata. ${ }^{23}$ Aspek tersebut meliputi bidang politik dan keamanan, diperlukan upaya memperkuat respon peradilan pidana terhadap perdagangan orang untuk melindungi korban perdagangan orang atau trafficking. Dalam bidang ekonomi memfasilitasi pergerakan tenaga kerja melalui penerbitan visa dan ijin pekerjaan untuk bisnis dan tenaga kerja terampil. Selain itu mengatur pengakuan kualifikasi profesional, melaksanakan dan mengembangkan pengembangan sumber daya manusia, serta memperkuat kapasitas pasar tenaga kerja. Dalam bidang sosial

${ }^{22}$ ASEAN Economic Community Blue Print, http:// asean.org/wp-content/uploads/archive/5187-10.pdf diakses pada tanggal 12 Oktober 2016, pukul 16.00 WIB

${ }^{23}$ Flavia Jurje dan Sandra Lavenex, Op.Cit, hlm. 7. budaya diperlukan pengembangan sumber daya manusia, mempromosikan prinsip "decent work" dan mempromosikan hakhak pekerja migrant.

Dalam MEA terdapat delapan profesi yang telah disepakati untuk terbuka bagi arus tenaga kerja terampil yaitu insinyur, arsitek, perawat, tenaga survei, tenaga pariwisata, praktisi medis, dokter gigi, dan akuntan. Dengan kualifikasi pekerja adalah yang termasuk kategori "skilled workers" dengan syarat minimum lama pengalaman kerja. Masing-masing profesi telah menetapkan standar dan kompetensi yang diperlukan di pasar ASEAN, yang tertuang dalam ASEAN Mutual Recognition Arrangement (MRA). Harus diperhatikan dalam kerangka MEA, bahwa, negara-negara anggota ASEAN tidak bertujuan untuk memfasilitasi arus tenaga kerja terampil yang sepenuhnya bebas tanpa pembatasan seperti yang umum dipahami. Perjanjian tentang the Movement of Natural Persons (MNP) dan ASEAN Comprehensive Investment Agreement (ACIA) tidak berlaku untuk individu yang mencari pekerjaan, kewarganegaraan, tempat tinggal, atau tempat tinggal permanen di negara anggota ASEAN lainnya. ${ }^{24} \mathrm{Hal}$ ini cukup

\footnotetext{
${ }^{24}$ ASEAN didirikan bertujuan untuk meningkatenaga kerja asingn pertumbuhan ekonomi negara-negara anggotanya dengan semangat persaudaraan dan semangat persamaan. Dalam Piagam ASEAN disebutenaga kerja asingn secara spesifik akan berusaha sekuat tenaga unntuk melakukan kerjasama ekonomi seefektif mungkin diantara sesamanya melalui perluasan perdagangan di wilayah Asia Tenggara. Salah satu program yang diinisiasi adalah menciptakan pasar tunggal ASEAN berbasis produksi diantara Negara anggota kawasan ASEAN yang kita kenal dengan program Masyarakat Ekonomi ASEAN (MEA). Terdapat 4 pilar penting dalam mewujudkan MEA. Keempat pilar tersebut antara lain arus barang yang bebas, arus jasa yang bebas, arus investasi yang bebas, dan arus modal yang lebih bebas. Keempat pilar ini memiliki payung hukum yang telah disepakati berupa ASEAN Trade in Goods Agreement (ATIGA) yang mengatur tentang arus barang yang bebas; ASEAN Framework Agreement on Services (AFAS) yang mengatur arus jasayang bebas, ASEAN Comprehensive Agreement on Investment (ACIA) yangmengatur arus investasi yang bebas, serta Chiang Mai Initiative Multilat-
} 
jelas, misalnya, bahwa ACIA hanya berlaku untuk individu yang dipekerjakan oleh perusahaan yang terdaftar di negara asalnya. Pada dasarnya MEA tidak menjamin mobilitas penuh bagi tenaga kerja, walaupun tenaga kerja tersebut sangat ahli, MEA hanya memfasilitasi arus bebas tenaga kerja ahli. Dalam hal ini MEA tidak seterbuka negara Uni Eropa (EU) atau Wilayah Ekonomi Eropa (EEA), di mana warga negara bisa bergerak bebas, tinggal, dan mencari pekerjaan di setiap Negara Anggota, terlepas dari tingkat keterampilannya. MEA juga kurang terbuka dibandingkan dengan kelompok regional yang lebih terbatas seperti CARICOM (organisasi politik dan ekonomi dari 15 negara-negara Karibia dan dependensi), yang memungkinkan untuk bebas visa masuk bagi tenaga kerja yang sangat terampil. ${ }^{25}$

Liberalisasi ekonomi dengan adanya MEA dan semakin terintegrasinya pasar tenaga kerja, akan menambah peluang lapangan kerja semakin luas lagi. Hal ini dapat menjadi sebuah solusi untuk mengurangi tingkat pengangguran dan pemberantasan kemiskinan. Hasil yang diharapkan dapat tercapai jika dibarengi kebijakan nasional yang mendukung. Arus bebas tenaga kerja juga merupakan keuntungan dari sisi pengusaha, memberikan pertambahan pasokan tenaga kerja. Persaingan untuk mendapatkan TKA yang terbaik akan mendorong pengusaha menawarkan upah yang menarik yang tentunya sebanding dengan yang ditawarkan negara asal tenaga kerja. Adanya perbedaan menyolok antara upah dalam negeri dan luar negeri akan menyebabkan terjadinya brain drain, yaitu langkanya tenaga kerja terampil di dalam negeri akibat berpindahnya tenaga kerja

eralisation (CMIM) yang mengatur tentang arus modal yang lebih bebas.

${ }^{25}$ Flavia Jurje dan Sandra Lavenex, Op. Cit. terampil ke negara lain yang memberikan keuntungan yang lebih besar. ${ }^{26}$

\section{Politik Hukum Harmonisasi Pen- gaturan tentang Keperawatan di In- donesia dalam Konteks Penyesuaian Standar Keperawatan di Masyarakat Ekonomi ASEAN (MEA)}

Sebagaimana dinyatakan sebelumnya, istilah politik hukum merupakan terjemahan Bahasa Indonesia dari istilah hukum Belanda rechtspolitiek, yang merupakan bentukan dari dua kata recht (hukum) dan politiek (politik). ${ }^{27}$ Hubungan hukum dengan politik dijelaskan oleh Max Weber bahwa hukum tidak dapat lepas dari kepentingankepentingan dan pengaruh termasuk kepentingan dan pengaruh politik. Hukum itu dipengaruhi kepentingankepentingan, baik itu kepentingan material maupun kepentingan-kepentingan ideal. ${ }^{28}$ Berdasarkan teori yang dikemukakan oleh Max Weber maka kepentingan yang diakomodir dalam pembuatan produk hukum ini adalah kepentingan profesi perawat baik yang ada di dalam negeri maupun yang akan bekerja di luar negeri dalam ruang lingkup negara anggota ASEAN. Adapun kepentingan ideal ini berkaitan dengan tujuan dari dibentuknya Negara Indonesia yang tercantum dalam alinea keempat Undang-Undang Dasar 1945 sendiri yaitu memajukan kesejahteraan umum. Kesejahteraan umum ini dapat dipandang sangat luas meliputi seluruh aspek yang berkaitan dengan profesi perawat.

Secara umum Profesi Perawat sudah diatur dalam Undang-Undang No. 38 Tahun 2014 tentang Keperawatan yang

${ }^{26}$ R. Winantyo, Rahmat Dwi Saputra, dkk, Masyarakat Ekonomi ASEAN (MEA) 2015, Memperkuat Sinergi ASEAN di Tengah Kompetisi Global, hak cipta Tim Biro Hubungan Studi Internasional Bank Indonesia, Jakarta: Elex Media Komputindo, hlm. 278.

${ }_{27}$ Imam Syaukani, A. Ahsin Thohari, Dasar-Dasar Politik Hukum, Jakarta: Rajawali Pers, 2013, hlm.19.

${ }^{28}$ Agung dan Asep, Ham, Kejahatan Negara Dan Imperialisme Modal, Pustaka Pelajar, 2001, hlm.27. 
selanjutnya disebut UU Keperawatan. Dengan adanya MEA, maka peraturan tentang keperawatan di Indonesia harus merujuk pada standar keperawatan yang disepakati dengan berlangsungnya MRA di MEA. Hal ini berkaitan juga dengan standar keperawatan, perlindungan hukum profesi perawat termasuk perawat asing yang akan bekerja di Indonesia dan bagaimana penyelesaian hukum apabila terjadi masalah hukum antara perawat asing dengan pasien di Indonesia. Namun demikian, saat ini belum terdapat peraturan terbaru terkait profesi perawat, UU Keperawatan sendiri disahkan sebelum MEA berlangsung yakni pada 17 Oktober 2017. Lebih lanjut, berdasarkan hasil wawancara penulis dengan Masfuri SkP,MN Ketua Bidang Hubungan Kerjasama Luar Negeri DPP Persatuan Perawat Nasional Indonesia selanjutnya disebut $\mathrm{PPNI}^{29}$, peraturan tentang keperawatan di Indonesia masih merujuk pada UU No. 38 Tahun 2014 tentang keperawatan dimana aturan ini dibuat sebelum berlangsungnya RMA di MEA. Sedangkan bagian hukum Kementrian Ketenagakerjaan saat diwawancara menyatakan bahwa peraturan mengenai tenaga kerja asing dari negara anggota ASEAN ini sedang disiapkan dengan melibatkan peran asosiasi profesi termasuk Kementerian Kesehatan. Secara teknis perawat dari negara-negara anggota ASEAN yang masuk ke Indonesia juga masih merujuk pada Peraturan Menteri Ketenagakerjaan Nomor 16 Tahun 2015 tentang Tata Cara Penggunaan Tenaga Kerja Asing sebagaimana diubah oleh Peraturan Menteri Ketenagakerjaan Nomor 35 Tahun 2015 tentang Perubahan Atas Peraturan Menteri Ketenagakerjaan Nomor 16 Tahun 2015 tentang Tata Cara Penggunaan Tenaga Kerja Asing.

29 Wawancara dengan Narasumber Bapak Masfuri SkP, MN. (Ketua Bidang Hubungan Kerjasama Luar Negeri DPP Persatuan Perawat Nasional Indonesia) Depok, 6 Maret 2017.

100 IUS Kajian Hukum dan Keadilan
Belum diaturnya secara spesifik mengenai arus jasa profesi perawat di Indonesia, mengharuskan Indonesia merujuk pada aturan sebelumnya. Hal ini tentu saja sedikit banyak berdampak pada kelancaraan dari agenda MEA di Indonesia khusus untuk profesi perawat. Politik hukum dari pemerintah terkait hal ini perlu diperhatikan.

Politik hukum adalah "kebijakan" yang diambil (ditempuh) oleh negara (melalui lembaganya atau pejabatnya) untuk menetapkan hukum mana yang perlu diganti, atau yang perlu dirubah, atau hukum mana yang perlu dipertahankan, atau hukum mengenai apa yang perlu diatur atau dikeluarkan agar dengan kebijaksakan itu penyelengaraan negara dan pemerintah dapat berlangsung dengan baik dan tertib sehingga tujuan negara (seperti mensejahterahkan rakyat) secara bertahap dan terencana terwujud. ${ }^{30}$ Dalam konteks aturan mengenai profesi perawat, pemerintah perlu merujuk pada kesepakatan dan standar yang disepakati bersama di tingkat ASEAN.

Jika merujuk pada penelusuan secara kepustakaan dan hasil wawancara maka dapat dilihat bahwa pemerintah nampaknya merasa belum perlu mengubah peraturan yang ada berkaitan dengan keperawatan di Indonesia. Padahal Negara anggota ASEAN lainnya sudah merubah kebijakan mereka terkait hal tersebut. Jika dibandingkan dengan Negara ASEAN lainnya maka dapat diasumsikan bahwa pemerintah menunjukkan ketidak-seriusan dalam mengahadapi MEA khususnya Profesi Perawat. Sebagai perbandingan, di Brunei Darussalam dan Vietnam perawat-perawat Asing yang masuk terdaftar melalui MRA ASEAN mendapatkan perlakuan secara khusus $^{31}$, artinya sudah ada aturan khusus

\footnotetext{
${ }^{30}$ H.Inu Kencana Syafie, dan Azhari, Sistem politik Indonesia, Bandung: Refika Aditama, 2005, hlm.17.

${ }^{31}$ Yoshifumi Fukunaga, Assessing the Progress of ASEAN MRAs on Professional Services, ERIA Discussion Paper Series, 2015, No. 2015- 21, hlm.21.
} 
mengakomodir MRA Perawat sehingga Brunei dan Vietnam bisa merasakah manfaat MRA Perawat lebih awal dari Indonesia.

Memang perlu diakui bahwa politik hukum satu negara berbeda dengan politik hukum negara yang lain. Akan tetapi perlu juga melihat perkembangan politik hukum intenasional dimana faktor-faktor yang akan menentukan politik hukum tidak semata-mata ditentukan oleh apa yang kita cita-citakan atau tergantung pada kehendak pembentuk hukum, praktisi atau para teoritisi belaka. Akan tetapi politik hukum juga ikut ditentukan oleh kenyataan serta perkembangan hukum di negara-negara lain serta perkembangan hukum internasional. ${ }^{32}$

Melihat perkembangan politik hukum internasional terdapat kekhawatiran dalam hal standar, apakah Indonesia bisa mengikuti kualitas praktik seperti di negara lain yang lebih baik dibandingkan di Indonesia. Permasalahanya, ketika kualitas mereka lebih baik maka akan terdapat potensi bahwa lebih banyak perawat luar negeri yang masuk Indonesia karena standarnya sudah melebihi dari yang diminta oleh Indonesia. Berbanding terbalik dengan kekhawatiran tersebut, memang hasil wawancara dengan PPNI menyatakan bahwa Indonesia tidak perlu khawatir dengan persaingan profesi perawat di ASEAN karena potensi perawat asing ke Indonesia cukup kecil. Perawat dari negara Anggota ASEAN akan datang ke Indonesia hanya ketika mereka mengalami surplus, kecuali Perawat dari Filipina. Negara Filipina dan Indonesia memiliki perbedaan yang besar dalam segi Bahasa, namun tidak dalam hal gaji. Lain halnya dengan Malaysia dan Indonesia yang tidak jauh berbeda dalam hal Bahasa, agama dan budayanya. Jika Malaysia membuka peluang bagi Indonesia, maka para perawat Indonesia akan berbondongbondong pergi ke Malaysia untuk bekerja

\footnotetext{
${ }^{32}$ Ibid, hlm 33
}

karena jumlah perawat di Indonesia sudah terlalu banyak. Disamping itu, penghasilan yang ditawarkan Malaysia lebih tinggi dibandingkan yang ditawarkan di Indonesia.

Politik hukum nasional salah satunya meliputi pembangunan hukum yang intinya adalah pembaruan terhadap ketentuan hukum yang telah ada dan yang dianggap usang, dan penciptaan ketentuan hukum yang baru yang diperlukan untuk memenuhi tuntutan perkembangan yang terjadi dalam masyarakat; : ${ }^{33}$ Politik hukum menganut prinsip double movement, yaitu selain sebagai kerangka pikir merumuskan kebijakan dalam bidang hukum (legal policy) oleh lembaga-lembaga negara yang berwenang, ia juga dipakai untuk mengkritisi produk-produk hukum yang telah diundangkan berdasarkan legal policy diatas. ${ }^{34}$ Pembangunan hukum dengan penciptaan hukum baru ini juga yang tampaknya diinginkan oleh PPNI dimana dengan adanya MEA terjadi harmonisasi berbagai macam peraturanperaturan, lembaga-lembaga pengatur keperawatan. Misalnya di dalam MEA terdapat The ASEAN Joint Coordinating Committee on Nursing (AJCCN), salah satu hutang Indonesia pada pertemuan ke 23 AJCCN yang lalu yaitu bahwa Indonesia harus memiliki konsil keperawatan. Tetapi sampai pertemuan yang terakhir di Semarang, Indonesia menunda pembentukan konsil keperawatan yang artinya seharusnya tahun 2016 sudah dibuat melalui Peraturan Pemerintah tentang konsil keperawatan sebagaimana amanat UU No. 38 Tahun 2014 belum bisa dipenuhi, hal ini menunjukkan bahwa untuk terjadi harmonisasi, saling pengakuan salah satunya dari sisi lembaga yang memberikan izin terhadap perawat.

Berkaitan dengan pembangunan hukum dalam dunia keperawatan juga dapat melihat pada kenyataan bahwa di

\footnotetext{
${ }^{33}$ Imam Syaukani, A. Ahsin Thohari, Op.Cit, hlm.31 ${ }^{34}$ Ibid, hlm.51.
} 
dunia terdapat dua konsep nursing pure atau nursing council. Indonesia tidak mengenal keduanya dan lebih cenderung kepada model lembaga sertifikasi profesi dengan berlandaskan Undang-Undang Nomor 36 Tahun 2014 tentang Tenaga Kesehatan. Menurut PPNI pada umumnya di negara-negara lain tidak ada model keperawatan atau kedokteran dibawah tenaga kerja. Semuanya itu seharusnya dibawah kementerian kesehatan. Kemungkinan itu hanya ada satu yaitu di Jerman itu dibawah E-Commerce. Jadi dengan berada di bawah kementrian kesehatan peraturannya berbeda dengan tenaga kerja pada umumnya, contohnya dalam sisi akselarasi profesi perawat dapat diuntungkan. Keuntungan lain misalnya dari standarisasi nanti misalnya standar kompetensi, PPNI akan melakukan upaya harmonisasi, tetapi kecenderungannya yang terjadi tidak ada harmonisasi yang ada hanyalah penyeragaman. PPNI memandang harmonis itu berbeda-beda boleh tetapi tetap saling mengakui, jadi yang ada hanyalah unifikasi. Misalnya Kompetensi perawat di Indonesia ada tiga, tetapi yang disepakati di ASEAN ada lima. Sehingga disepakati bahwa PPNI memiliki keinginan bentuk bangunannya sama, tapi masalah isinya beda itu menjadi kewenangan negara masing-masing. Saat ini yang sedang dilakukan kajian adalah penelaahan ke standar kurikulum, yang nanti suatu saat akan terjadi penelahaan keseluruhan dan fungsi-fungsi stakeholder yang ada di seluruh negara-negara anggota ASEAN. Pada saat PPNI mengetahui fungsi stakeholder dari negara lainnya, kita jadi dapat membentuk fungsi yang tidak dimiliki Indonesia untuk dapat melakukan fungsi keseluruhan, karena adanya force pressure dari ASEAN yang masuk sebagai bagian dari kesepakatan tersebut.

Dari sisi positif lainnya, penghargaan terhadap perawat itu masih rendah. Sehingga kita bisa berbagi best practice dengan banyak negara lainnya, sehingga nanti memiliki peluang bahwa Indonesia akan didorong pada standar good practice darinegaralain. Indonesiaitu saatinimasih tertinggal dari Thailand dan Malaysia. Sehingga dengan adanya standarisasi maka dapat memotivasi Indonesia untuk dapat dapat lebih maju karena banyak sekali hal yang harus dilakukan oleh Indonesia. Jadi, kalau manfaat yang didapatkan oleh Indonesia tentu banyak sekali tetapi tetap banyak hal yang harus diselaraskan.

Profesi Perawat dituntut untuk bekerja dengan baik, menghasilkan output yang baik, tingkat kepuasan pasien tinggi, human error nya rendah, length of stand nya rendah tetapi itu tidak adil karena stuffing nya tidak distandarisasi, misalnya pendidikannya tidak standar, komposisi pendidikan diploma dan S1 perawat standarnya tidak seimbang. Kalau di negara asing D3 itu sudah hampir tidak ada, D3 itu hanya membantu sedikitsedikit. Minimal harus perawat yang sudah spesialisasi. Dengan adanya hal tersebut nantinya Indonesia akan memandang untuk mencapai ouput seperti itu Indonesia harus bisa mencontoh negara lain. Sebenarnya hal ini adalah potensi baik meskipun bisa dianggap sebagai potensi ancaman karena mengetahui negara Indonesia masih banyak kekurangan. Jadi nanti akan muncul dengan stuffing seperti ini, akan muncul biaya service dan cost unit untuk perawat. Jadi nanti akan muncul untuk pembiayaan tentang cost keperawatan yang sudah ditetapkan kontennya. Indonesia sebenarnya paling murah, padahal standar Indonesia sendiri tidak begitu jelek, sekarang BPJS saja sudah mengarah kesana. Masalah yang terjadi di Indonesia, di dalam profesi kesehatan terdapat ketimpangan yakni yang menguasai $80 \%$ kesehatan adalah dokter, sehingga nanti akan ada aturan bahwa maksimum perbedaan gradasi pendapatan tertinggi dan terendah berapa kali agar dapat terdistribusi dengan baik. Sekarang untuk kompetensi sudah 
dilakukan. Misalnya semua tenaga kerja kesehatan di Rumah Sakit sudah ditetapkan standarnya. Dengan cara seperti itu, negara akan diarahkan untuk membuat sistem yang lebih adil bagi tenaga kerja kesehatan dan keperawatan. Sehingga perubahan tersebut dapat memberikan dampak stabilitas.

Pandangan dari PPNI merupakan hal yang dapat di akomodir oleh pemerintah sebagaimana Mahfud M. D sendiri berpendapat dalam konteks politik hukum jelas bahwa hukum adalah "alat" yang bekerja dalam "sistem hukum" tertentu untuk mencapai "tujuan" Negara atau "cita-cita" masyarakat Indonesia. Oleh sebab itu, pembahasan mengenai politik hukum nasional harus didahului dengan penegasan tentang tujuan negara. ${ }^{35}$ Cita-cita masyarakat Indonesia sendiri yaitu memajukan kesejahteraan umum. Kesejahteraan umum profesi perawat ini dapat dicapai dengan harmonisasi peraturan perundang-undangan yang dapat membawa pada kepastian hukum, keadilan hukum dan kemanfaatan hukum. Harmonisasi hukum sendiri memiliki fungsi pencegahan dan penanggulangan. Dalam konteks pengaturan keperawatan, harmonisasi hukum ditujukan untuk mencegah adanya kesenjangan antara perawat asal Indonesia dan perawat asal negara anggota ASEAN lainnya. Kesenjangan ini dapat dijembatani dengan adanya harmonisasi standardisasi dan sertifikasi perawat di ASEAN sehingga arus bebas profesi perawat di Indonesia dapat berjalan tanpa hambatan berarti. Sedangkan fungsi penanggulangan dapat dikaitkan dengan penyelesaian masalah dalam praktek keperawatan dalam kerangka MEA.

Harmonisasi dapat mempengaruhi bentuk dari hukum nasional bahkan sumber hukum nasional dari sistem hukum

${ }^{35}$ Moh. Mahfud MD, Membangun Politik Hukum, Menegakan Konstitusi, Jakarta: Rajawali Pers, 2011, hlm. 17. suatu Negara. Belum lagi, penegakan dan pengenaan sanksi memiliki tantangan tersendiri. Guna menjembataniperbedaanperbedaan dalam hal pengaturan tentang keperawatan di masing-masing Negara anggota ASEAN maka perlu dilakukan suatu proses standardisasi di tingkat regional ASEAN dan nasional.

Standar merupakan suatu dokumen yang meletakkan suatu syarat, spesifikasi, pedoman atau karakteristik yang dapat menjamin bahwa materi, produk, proses dan jasa cocok dan sesuai dengan tujuannya. Berdasarkan the International Organization for Standardization (ISO), standar memudahkan proses harmonisasi suatu produk atau jasa, membuat industri lebih efesien dan menghilangkan hambatan-hambatan dalam perdagangan internasional. ${ }^{36}$ Dalam konteks profesi perawat, standar mendorong suatu kualitas yang baik dari seorang pemangku profesi dan memudahkan dalam hal pengenaan sanksi dalam hal pemangku profesi tidak memenuhi standar.

Arus jasa profesi perawat di ASEAN didasarkan pada ASEAN Mutual Recognition Agreement on Nursing Services (MRA Perawat). Tujuan dari MRA Perawat adalah memfasilitasi mobilitas perawat profesional di ASEAN, wadah pertukaran informasi dan keahlian berdasarkan suatu standar dan kualifikasi tertentu dan mendorong adopsi praktikpraktik terbaik (best practice) dari jasa perawat serta menyediakan pembangunan kapasitas dan pelatihan bagi perawat.

Dalam tulisan ini, penulis membatasi pada beberapa standar mengenai pendidikan, perizinan, penggajian dan penyelesaian sengeketa. Hal ini didasarkan pada pandangan bahwa perbedaan terbesar antara masing-masing Negara ASEAN

\footnotetext{
${ }^{36}$ Samuel D. Scoles, Harmonization of Standard and Mutual Recognition Agreements on Conformity Asessment in Indonesia, Malaysia, Thailand and Vietnam, ERIA Research Project Report, 2015, No. 15 , hlm. 2
} 
adalah terkait poin tersebut dan hal ini menjadi amanat dalam MRA Perawat.

Pendidikan keperawatan di Indonesia memiliki perbedaan dengan beberapa Negara ASEAN lainnya. Di Indonesia masih terdapat pendidikan jenjang Diploma yang berlangsung selama kurang lebih 3 tahun masa pendidikan, 4 tahun sarjana keperawatan, 2 tahun magister atau master keperawatan dan 3 tahun doktor dalam bidang keperawatan. Sementara di Negara seperti Laos, Filipina dan Thailand tidak mengenal jenjang Diploma meskipun Vietnam, Singapura dan Malaysia tidak berbeda dengan Indonesia. Permasalahannya adalah untuk dapat diangkat sebagai Perawat Terdaftar dalam ASEAN, minimal harus memiliki gelar Sarjana Keperawatan. ${ }^{37}$ Bahkan di Indonesia, seorang profesional adalah yang sudah menyelesaikan tingkat Sarjana dan Ners. Konsekuensinya adalah perawat dengan latar belakang pendidikan Diploma tidak menjadi bagian dari arus bebas profesi perawat yang diakui di ASEAN. ${ }^{38}$

Terkait hal ini, Indonesia perlu melakukan harmonisasi terkait standar minimum pendidikan untuk dapat menjadi Perawat Terdaftar di ASEAN. Indonesia perlu meningkatkan program pendidikan dari Diploma menjadi Sarjana. Bagi perawat yang masih berpendidian Diploma didorong untuk melanjutkan ke jenjang yang lebih tinggi yakni Sarjana. Lebih lanjut, Pasal 5 UU Keperawatan perlu dikaji ulang oleh karena masih memperbolehkan pendidikan vokasi. Boleh saja aturan ini tidak diubah namun sebagai konsekuensi maka lulusan Diploma tidak dapat bekerja di Negara ASEAN lainnya.

Perawat yang hendak menjalankan profesinya sebagai perawat atau dengan

\footnotetext{
37 Yupin Aungsuroch, Joko Gunawan, Nurse Preparation towards ASEAN Economic Community 2015, International Journal of Health Sciences \& Research, 2015, Vol.5, Issue. 3, hlm. 367. ${ }^{38}$ Ibid.
}

kata lain akan menjalankan Praktik Keperawatan, diwajibkan untuk memilki STR (SuratTandaRegistrasi). STR tersebut diberikan oleh Konsil Keperawatan. Lebih lanjut, untuk mendapatkan STR, Perawat harus memenuhi beberapa sebagaimana dinyatakan dalam Pasal 18 ayat (3) UU Keperawatan, yaitu: a. memiliki ijazah pendidikantinggiKeperawatan;b.memiliki Sertifikat Kompetensi atau Sertifikat Profesi; c. memiliki surat keterangan sehat fisik dan mental; d. memiliki surat pernyataan telah mengucapkan sumpah/ janji profesi; dan e. membuat pernyataan mematuhi dan melaksanakan ketentuan etika profesi. Dalam hal perawat Indonesia memenuhi syarat tersebut maka Perawat Indonesia memenuhi satu dari beberapa syarat untuk diakui sebagai Perawat Asing di ASEAN. Namun tantangannya adalah Perawat Indonesia harus memenuhi syarat yang tidak semata-mata diberikan oleh Indonesia sebagai Negara Asal. Tantangan lainnya adalah sampai dengan saat ini, Konsil Keperawatan belum juga dibentuk di Indonesia. Padahal, Pasal 63 UU Keperawatan mewajibkan dibentuknya Konsil Keperawatan paling lama 2 (dua) tahun sejak UndangUndang ini diundangkan, artinya, Konsil Keperawatan sudah seharusnya terbentuk pada Oktober 2016 lalu.

Belum dibentuknya Konsil Keperawatan tidak hanya mengabaikan amanat UU Keperawatan tetapi juga berpotensi menghambat jalannya MRA Perawat di Indonesia. Upaya untuk melakukan standarisasi profess perawat tentu tidak berjalan lancar karena di Indonesia, standar kompetensi kerja disusun oleh Organisasi Profesi Perawat dan Konsil Keperawatan dan ditetapkan oleh Menteri. Konsil Keperawatan juga bertugas melakukan pembinaan dan pengawasan mutu Perawat sesuai dengan kewenangannya. Konsil Keperawatan sendiri mempunyai wewenang untuk menyetujui atau menolak permohonan 
Registrasi Perawat, termasuk Perawat Warga Negara Asing. Selain itu Indonesia juga belum memiliki Standar Kompetensi dengan 5 ASEAN core competency. ${ }^{39}$ Pasal 60 UU Keperawatan memang menyatakan bahwa selama Konsil Keperawatan belum terbentuk, permohonan untuk memperoleh STR yang masih dalam proses diselesaikan dengan prosedur yang berlaku sebelum Undang-Undang ini diundangkan, artinya terkait dengan Izin dan Penyelenggaraan Praktik Perawat masih merujuk pada Peraturan Menteri Kesehatan RI Nomor 17 Tahun 2013 tentang Perubahan atas Peraturan Menteri Kesehatan Nomor HK.02.02/ MENKES/148/I/2010.

Syarat lainnya untuk dapat diakui sebagai Perawat Asing di Indonesia adalah memenuhi kualifikasi perawat dan memenuhi syarat-syarat (mengikuti tes medis pribadi dan mengikuti suatu program atau penilaian kompetensi tertentu) yang ditentukan oleh Negara Penerima sebagaimana yang dinyatakan dalam Article III MRA Perawat. Lebih lanjut, Perawat Indonesia juga wajib mengikuti Kode Etik dan Peraturan Keperawatan Negara Penerima, mengikuti skema pertanggungjawaban asuransi dan menghormati budaya dan agama di Negara Penerima.

Terkait dengan Kode Etik dan Peraturan Keperawatan, tentu saja lebih mudah karena dapat dilakukan melalui harmonisasi sehingga isi-isi dalam Kode Etik dan Peraturan kurang lebih sama antara satu Negara dengan Negara lainnya di ASEAN. Namun untuk budaya dan agama, tentu terdapat beberapa kesulitan tersendiri. Negara-negara di ASEAN memiliki budaya dan agama yang berbedabeda. Faktor mayoritas budaya dan agama sedikit banyak mempengaruhi kehidupan sehari-hari di masing-masing Negara.

39 PPNI, "ASEAN MEETING PPNI Mengawal MEA untuk Kepentingan Bangsa", diakses dari http:// ppni-inna.org/index.php/public/information/news-detail/9, pada tanggal 11 Agustus 2017, pukul 11.30 WIB.
Sebagai contoh di Indonesia dan Malaysia, penduduk mayoritas adalah beragama Islam, konsekuensinya kehidupan seharihari masyarakat harus melihat pada hukum halal dan haram umat Islam. Hal ini berdampak pada teknis kerja seorang perawatan dan pemilihan makanan dan minuman oleh perawat bagi pasiennya. Di Vietnam dan Thailand juga berlaku hal yang sama mengingat masyarakat disana kebanyakan beragama Budha sehingga memiliki aturan tersendiri yang dapat saja bersinggungan dengan profesi perawat.

Dalam menghadapi tantangan ini, artinya Indonesia harus bekerja sama dengan Asosiasi Perawat di Negara Tujuan dalam hal pengenalan praktik terbaik (best practice) dari profesi perawat didasarkan pada karakteristik Negara masingmasing. Artinya, masing-masing Negara perlu menyiapkan pelatikan kompetensi budaya (transcultural competency). Guna mewujudkan hal tersebut Indonesia perlu mengadopsi perilaku-perilaku yang mendorong kompetensi pemahaman budaya, mengembangkan kesadaran akan perbedaan budaya dan melakukan penilaian atas kompetensi budaya seorang perawat. $^{40}$ Dalam hal seorang perawat telah lulus akan kompetensi ini, barulah perawat tersebut diizinkan untuk bekerja di Negara tujuan.

Tidak dapat dipungkiri bahwa, gaji atau honorarium adalah salah satu alasan utama seoang perawat mau bekerja di Negara lain. Konsekuensinya, Negara maju akan menjadi target utama mengingat potensi pendapatan yang lebih besar. Perbedaan terkait standarisasi gaji tentu menjadi persoalan ketika arus bebas profesi perawat semakin terbuka. Harmonisasi terkait standar penggajian perlu dilakukan, mengingat sengketa ketenagakerjaan sering terjadi dengan alasan penggajian. Kondisinya lebih mudah dalam hal perawat dari Negara berkembang (dengan gaji yang lebih

${ }^{40}$ Ibid. 
rendah) bekerja di Negara maju (dengan gaji yang lebih besar), namun sebaliknya potensi sengketa lebih mungkin terjadi jika perawat dari Negara maju bekerja di Negara berkembang dengan gaji yang lebih kecil, sementara Negara berkembang berharap dengan masuknya perawat asing, dapat memungkinkan alih keterampilan dan teknologi.

Harmonisasi mengenai pengupahan memang tidak bisa dilakukan dalam pemaknaan bahwa upah perawat di satu Negara harus sama dengan Negara lainnya, namun dapat dilihat pada kebutuhan di masing-masing Negara. Indonesia perlu melakukan standarisasi pengupahan dengan merujuk pada faktor lamanya masa kerja; faktor profesionalisme, keterampilan dan kecakapan seorang perawat; faktor volume dan beban kerja serta besar-kecilnya resiko pekerjaan; aspek kepribadian; atau tinggi-rendahnya kualifikasi pendidikan (sebagai basic start awal dalam bekerja); dan lain-lain sebagainya. Guna menghindari penilaian yang bersifat subjektif terhadap faktor-faktor tersebut, Indonesia perlu merumuskan struktur dan skala upah yang dibuat atas dasar beberapa ukuran penilaian, sehingga terukur (transparan) dan dapat dipertanggung-jawabkan (responsible dan accountable). Selain mempermudah mekanisme pengupahan, hal ini juga memperkecil potensi sengketa antara perawat baik lokal maupun asing dengan tempat kerja.

Terakhir, mengenai penyelesaian sengketa yakni antar rekan sejawat perawat, perawat asing dengan asosiasi dan utamanya perawat dengan pasien. Sengketa dalam bidang keperawatan merupakan hal yang tidak dapat sepenuhnya dihindarkan di Indonesia. Kemungkinan-kemungkinan seperti malpraktek, ketidakpuasan pelayanan, pelanggaran disiplin dan pelanggaran etika profesi keperawatan merupakan kasus yangcukup sering terjadi. Secara garis besar penyelesaian sengketa dapat diselesaikan melalui proses peradilan (litigasi) dan di luar proses peradilan (non litigasi). Penyelesaian sengketa di luar proses peradilan (non litigasi) dapat diselesaikan melalui mekanisme Alternative Dispute Resolution (ADR). Penyelesaian sengketa ini meliputi sengketa hubungan industrial dan sengketa medik, artinya Indonesia juga harus membuat mekanisme penyelesaian sengketa berdasarkan jenis sengketa tersebut. Tantangan terbesar lainnya adalah kurangnya struktur atau organ yang kuat di ASEAN. Masingmasing Negara memiliki rencana masingmasing sementara Sekretariat ASEAN tidak memiliki kewenangan yang cukup dan mungkin diabaikan oleh Negara anggota, berbeda jika dibandingkan dengan Parlemen Eropa. ${ }^{41}$ Untuk itu, ASEAN perlu memikirkan haltersebut dan membentuk organ ASEAN yang kredibel dan kuat.

\section{SIMPULAN}

Masyarakat Ekonomi ASEAN (MEA) merupakan bentuk kerjasama di antara negara-negara anggota ASEAN melalui integrasi sektor ekonomi dalam suatu pasar tunggal di kawasan Asia Tenggara. Diantara hal-hal yang disepakati di MEA, arus bebas tenaga kerja profesional merupakan salah satu yang penting untuk dikaji. Patut diakui bahwa di satu sisi, pembukaan pasar tenaga kerja mendatangkan manfaat yang besar. Selain dapat menciptakan jutaan lapangan kerja baru, skema ini juga dapat meningkatkan kesejahteraan ratusan juta orang yang hidup di Asia Tenggara. Namun disisi lain, terdapat ketakutan bahwa, Negara yang tidak mempersiapkan peraturannya dan sumber dayanya dengan baik maka akan merasakan kerugian lebih banyak daripada keuntungan yang didapat.

\footnotetext{
${ }^{41}$ Simon Pettman, Standards Harmonisation in ASEAN: Progress, Challenges and Moving Beyond 2015, ERIA Discussion Paper Series, 2013, hlm. 25.
} 
Di sisi inilah politik hukum memainkan perannya untuk menciptakan sebuah peraturan keperawatan yang mampu menciptakan sistem hukum yang transparan, independen dan tidak memihak, karena keberadaan peraturan perundang-undangan dan perumusan Pasal merupakan dasar dan penghubung dari Politk luar negeri yang diusung melalui suatu arus bebas tenaga kerja. Menjadi jelas bahwa politik hukum yang tepat dalam upaya pengaturan profesi perawat dalam konteks Masyarakat Ekonomi ASEAN (MEA) adalah suatu keharusan. Indonesia sebagai pihak dalam MEA khususnya Mutual Recognition Agreement on Nurse (MRA Perawat) perlu menentukan kebijakan yang tepat dalam menyikapi arus bebas jasa perawat di ASEAN.

Politik hukum yang saat ini dapat dilakukan Indonesia adalah dengan upaya harmonisasi standar-standar pemangku profesi yang berkualitas melalui produk perundang-undangan yang komprehensif. Standarisasi tersebut mencakup pendidikan, perizinan, pengupahan dan penyelesaian sengketa. Dalam bidang pendidikan, Indonesia harus memperbaharui program dan kurikulum pendidikan keperawatan yang mana lulusannya secara administrasi dan teknis memenuhi syarat sebagai Perawat Terdaftar di ASEAN. Hal ini ditujukan agar perawat Indonesia tidak hanya mampu bersaing di Tanah Air tetapi juga siap bersaing di Negara ASEAN lainnya. Indonesia dengan jumlah perawat yang besar perlu melihat pasar ASEAN lainnya. Namun tentu saja hal tersebut harus diimbangi dengan kualitas dan perizinan yang baik. Mekanisme perizinan yang jelas dan dapat dipertanggungjawabkan dapat menjadi bagian dari bentuk perlindungan perawat Indonesia ketika bekerja di Negara ASEAN lainnya. Hal ini harus dilakukan secara seimbang dan adil, artinya Indonesia pun harus menunjukan perlakuan non-diskriminasi terhadap Perawat Asing yang bekerja di Indonesia. Standar perizinan yang transparan dan terukur dapat memperkecil kemungkinan masing-masing Negara ASEAN memberlakukan standar perizinan yang diskriminatif, selain itu, apabila Indonesia menunjukan itikad baik maka Negara ASEAN lainnya tidak bisa beralasan untuk memperlakukan Perawat Indonesia secara tidak adil. Lebih lanjut, standar pengupahan yang jelas dan terukur berdasarkan suatu struktur dan ukuran tertentu dapat mengurangi kemungkinan sengketa antara perawat dengan pemberi kerja. Lebih lanjut, Indonesia juga perlu membuat standar penyelesaian sengketa baik yang bersifat hubungan industrial maupun medik. Penyelesaian sengketa tersebut juga disediakan melalui pilihan hukum (choice of law) dalam bentuk litigasi maupun non-litigasi. Terakhir, Indonesia perlu menyiapkan setiap peraturan yang dibutuhkan baik amanat dari MRA Perawat maupun amanat dari UU Keperawatan, yang salah satunya adalah pembentukan Konsil Keperawatan.

\section{DAFTAR PUSTAKA}

\section{Buku}

Agung dan Asep, 2001, Ham, Kejahatan Negara Dan Imperialisme Modal, Pustaka Pelajar.

Andrew Heywood, 2004, Political Theory: An Introduction, 3rd Edition, New York: Palgrave Macmillan.

C.S.T. Kansil, 2002, Pengantar Ilmu Hukum, Jakarta: Balai Pustaka.

Frank Garcia, 2013, Theories of Justice and International Economic Law, Research Handbook on Global Justice and International Economic Law John Linarelli ed. Northhampton, MA: Edward Elgar.

Guntur Sugiyarto and Dovelyn Rannveig 
Agunias. 2014, A 'Freer' Flow of Skilled Labour within ASEAN: Aspirations, Opportunities and Challenges in 2015 and Beyond, Bangkok and Washington, D.C.: International Organization for Migration and Migration Policy Institute.

H.Inu Kencana Syafie, dan Azhari, 2005, Sistem politik Indonesia, Bandung: Refika Aditama.

Imam Syaukani, 2013, A. Ahsin Thohari, Dasar-Dasar Politik Hukum, Jakarta: Rajawali Pers.

Koentjoroningrat, 1979, Metode-Metode

Penelitian Masyarakat, Jakarta: Gramedia.

Marius Widjajarta, 2011, Laporan Akhir Tim Pengkajian tentang Hak dan Kewajiaban Tenaga Kesehatan, Badan Pembinaan Hukum Nasional.

Moh. Mahfud MD, 2011, Membangun Politik Hukum, Menegakan Konstitusi, Jakarta: Rajawali Pers.

Prihadjo, 1995, Praktik Keperawatan Profesional Konsep Dasar dan Hukum, Jakarta : EGC.

R. Winantyo, Rahmat Dwi Saputra, dkk, ) 2015, Masyarakat Ekonomi ASEAN (MEA), Memperkuat Sinergi ASEAN di Tengah Kompetisi Global, hak cipta Tim Biro Hubungan Studi Internasional Bank Indonesia, Jakarta: Elex Media Komputindo.

Ronny Hanitijo Soemitro, 1985, Metodologi Penelitian Hukum, Jakarta: Ghalia Indonesia.

Sri Soemantri, 2006, Prosedur dan Sistem Perubahan Konstitusi Dalam Batang Tubuh UUD 45 (sebelum dan Sesudah Perubahan UUD 45), Bandung: Alumni.
Jurnal

Chia, S. Y., Free Flow of Skilled Labor in the AEC', in Urata, S. and M. Okabe (eds.), Toward a Competitive ASEAN Single Market: Sectoral Analysis. ERIA Research Project Report, 2011, No. 2010-03.

Flavia Jurje dan Sandra Lavenex, ASEAN Economic Community: what model for labour mobility?, Bern: World Trade Institute of the University of Bern Working Paper, 2015, No.2015/02.

Hikmahanto Juwana, Politik Hukum UU Bidang Ekonomi di Indonesia, Jurnal Hukum, 2005, Vol. 01, No. 1.

M. Ilham F. Putuhena, Politik Hukum Perundang- und angan: Mempertegas Reformasi Legislasi yang Progresif, Jurnal Rechtsvinding, Media Pembinaan Hukum Nasional, 2013, Vol.2, No. 3.

Samuel D. Scoles, Harmonization of Standard and Mutual Recognition Agreements on Conformity Asessment in Indonesia, Malaysia, Thailand and Vietnam, ERIA Research Project Report, 2015, No. 15.

Sarah Huelser dan Adam Heal, Moving Freely? Labour Mobility in ASEAN, ARTNeT Policy Brief,2014, No. 40.

Silvi Ch. Suman, Perkembangan ASEAN Framework Agreement on Services (AFAS) dan Kesiapan Indonesia, Buletin KPI, 2011, Edisi OOL/KP/2011.

Simon Pettman, Standards Harmonisation in ASEAN: Progress, Challenges and Moving Beyond 2015, ERIA Discussion Paper Series, 2013. 
Yohanes Hermanto Sirait, Demson Tiopan | Politik Hukum Pengaturan Profesi Perawat Dalam Upaya.....

Yoshifumi Fukunaga, Assessing the Progress of ASEAN MRAs on Professional Services, ERIA Discussion Paper Series, 2015, No. 2015- 21.

Yupin Aungsuroch, Joko Gunawan, Nurse Preparation towards ASEAN Economic Community 2015, al of Health Sciences \& Research, 2015, Vol.5, Issue. 3.

\section{Peraturan Perundang-Undangan:}

Undang-Undang Dasar Republik Indonesia Tahun 1945.

Undang-Undang Nomor 23 Tahun 2003 tentang Tenaga Kesehatan.

Undang-Undang Nomor 38 Tahun 2014 tentang Keperawatan.

\section{Wawancara dan Tugas akhir}

Masfuri SkP, MN. (Ketua Bidang Hubungan Kerjasama Luar Negeri DPP Persatuan Perawat Nasional Indonesia) Depok, 6 Maret 2017.

Cindy Cephanie Manek, Implikasi Pemberlakuan Ketentuan ASEAN Framework Agreement on Services (AFAS) Terhadap Jabatan Notaris, Denpasar: Magister Kenotariatan, 2014.

\section{Internet:}

Association of Southeast Asia Nation, ASEAN Economic Community Blue Print, 2008, http://asean. org/wp-content/uploads / archive/5187-10.pdf, diakses tanggal 12 Oktober 2016.

PPNI, ASEANMEETING PPNI Mengawal MEA untuk Kepentingan Bangsa, 10 Juli 2017, http://ppni-inna.org/ index.php/public/information/ news-detail $/ 9$, diakses tanggal 11 Agustus 2017.

Tempo, Jumlah Pengangguran RI 5,5 Persen per Februari 2016,
17 Agustus 2016, https:// b is nis.te m po.co/read/ news/2016/08/17/090796741/ jumlah-pengangguran-ri-5-5persen-per-februari-2016, diakses tanggal 5 Oktober 2016.

www.artnetontrade.org, diakses tanggal 12 Oktober 2016. 